\title{
Site effect studies following the 2016 Mw 6.0 Amatrice Earthquake (Italy): the Emersito Task Force activities
}

\author{
GIOVANNA CUlTRERA ${ }^{*}$, EZIO D' AlEMA ${ }^{2}$, SARA AMOROSO ${ }^{3}$, BARBARA ANGIONI ${ }^{1}$, \\ PAOLA BORDONI ${ }^{1}$, LUCIANA CANTORE ${ }^{3}$, FABRIZIO CARA ${ }^{1}$, ARRIGO CASERTA ${ }^{4}$, ROCCO COGLIANO ${ }^{5}$, \\ MARIA D’ AMICO ${ }^{2}$, GIUSEPPE Di GIULIO ${ }^{3}$, DEBORAH Di NACCIO ${ }^{3}$, DANIELA FAMIANI ${ }^{1}$, \\ CHIARA FELICETTA ${ }^{2}$, ANTONIO FODARELLA ${ }^{5}$, SARA LOVATI ${ }^{2}$, LUCIA LUZI ${ }^{2}$, \\ Claudia Mascandola ${ }^{2}$, Marco Massa ${ }^{2}$, Alessia Mercuri ${ }^{1}$, GiUliano Milana ${ }^{1}$, \\ FRANCESCA PACOR ${ }^{2}$, MARTA PischiUTTA ${ }^{1}$, STEFANIA PUCILlO ${ }^{5}$, RODOLFO PUGLiA ${ }^{2}$, \\ GAETANO RICCIO ${ }^{5}$, GABRIELE TARABUSI ${ }^{1}$, MAURIZIO VASSALLO ${ }^{3}$ \\ 1'Istituto Nazionale di Geofisica e Vulcanologia, Sezione Roma1, Roma, Italy \\ 2Istituto Nazionale di Geofisica e Vulcanologia, Sezione di Milano, Milano, Italy \\ 3Istituto Nazionale di Geofisica e Vulcanologia, Sezione Roma1, L'Aquila, Italy \\ 4Istituto Nazionale di Geofisica e Vulcanologia, Sezione CNT, Roma, Italy \\ 5Istituto Nazionale di Geofisica e Vulcanologia, Sezione Roma1, Grottaminarda (AV), Italy \\ * giovanna.cultrera@ingv.it
}

\begin{abstract}
On August 24, 2016, at 01:36 UTC a MW 6.0 earthquake struck an extensive area of the Central Apennines (Italy) between the towns of Norcia and Amatrice. Due to the mainshock magnitude and the widespread damaging level of buildings in the epicentral area, the Emersito task force has been mobilized by the Istituto Nazionale di Geofisica e Vulcanologia (INGV). The aim of Emersito is to carry out and coordinate the monitoring of local site effects, caused by geological and geomorphological settings. During the first days of the seismic emergency, Emersito installed a temporary seismic network for site effect studies at 4 municipalities close to the epicentral area (Amandola, Civitella del Tronto, Montereale and Capitignano), using 22 stations equipped with both velocimetric and accelerometric sensors. The selection of the sites where stations have been installed was mainly driven by the proximity to the epicentral area (without interfere with the rescue operations) and by peculiar geologic and geomorphologic settings (topographic irregularities, fault zones, alluvial plains). Preliminary analyses performed on ambient noise and aftershocks signals show that directional amplification effects may have occurred at stations installed on the top of topographic irregularities. We also observed the lengthening and amplification of the seismograms and a variability of the peaked frequency across the sedimentary basin between Montereale and Capitignano, probably related to a different thickness of the deposits. Further analyses are necessary to assess the correlation with surface geology.
\end{abstract}




\section{INTRODUCTION}

$\mathrm{T}$ The earthquake ground-motion depends on the source process, on the propagation of the incoming wave-field through the crustal medium, and on the transmission of the seismic waves from bedrock to the Earth surface (free-field motion). The last contribution is known as site effect, and substantially modifies the amplitude, the frequency content and duration of the seismic waveforms.

Three main types of site effects can be identified: impedance contrast between bedrock and softer soil, the lateral heterogeneities in the elastic and/or geometrical properties of the soil and the topographic settings that can produce 2D or 3D effects.

Site effects due to soft soil layers (e.g. alluvial or sedimentary cover) overlapping hard rock produce seismic wave amplification whose extent depends on the impedance contrast between different layers. These effects are usually modeled by $1 \mathrm{D}$ wave propagation through the soil column.

When lateral heterogeneities of the subsoil mechanical properties are not negligible (e.g. sediment filled valleys), 2D or 3D geometries are more appropriate to describe the complexity of the ground motion (Kawase, 1996; Bindi et al., 2009; Chaljub et al., 2010; Di Giulio et al., 2016). In the last decade particular attention has been devoted to the ground motion directional amplification in fault damage zones, related to fracture networks and the resulting stiffness anisotropy of the rock mass (Pischiutta et al., 2012).

Concerning the topographic effects, a correla- tion between pattern of damage and topographic elevation has been recently investigated (Paolucci, 2002; Massa et al., 2014), although there are fewer evidences compared to the previous two types of site effects.

Usually, these studies use seismic noise and background seismicity because stronger events are available for a target area during a seismic sequence only.

Emersito is a task force of the Istituto Nazionale di Geofisica e Vulcanologia (INGV) that involves several headquarters (Milano, Roma, L'Aquila, Grottaminarda; Italy). Its aim is to coordinate and carry out seismic monitoring to investigate possible site effects caused by seismic events of moderate-to-large magnitude $(M \geq 5)$ in the Italian territory. In case of relevant seismic sequences, a rapid installation of temporary seismic stations is fundamental to seismic monitoring, to the research in the field of seismic hazard and, in some cases, to support post-emergency activities (e.g. microzonation studies). Emersito operated for the first time during the Emilia 2012 sequence (Bordoni et al, 2012), and it was officially established in 2015 (DDG, 2015); mobilization procedures have been test during the INGV Emergency simulation performed on 2015 (Pondrelli et al, 2016).

On August 24, 2016 (01:36 UTC) a Mw6.0 earthquake struck an extensive area in the Central Apennines (Italy) between the municipalities of Norcia and Amatrice. The epicenter was located by the INGV close to the Accumoli village. A large aftershock ( $\mathrm{M}_{\mathrm{w}} 5.3$, August 24 02:33 UTC) and over 9000 aftershocks have been located up to September 16, 2016, in an 
extended area of about $50 \mathrm{~km}$ in the Appennine direction (from the town of Ussita to the North, to the lake of Campotosto in the South), and about $15 \mathrm{~km}$ width (INGV working group, 2016). In the first days of the seismic emergency (August 24t ${ }^{\text {th }}-25^{\text {th }}, 2016$ ), we have chosen several urban areas located at the margin of the epicentral area and characterized by geological and structural features able to produce local site effects (Figure 1). Several issues were considered for the selection of the areas: availability of geological maps and first level microzonation studies, location of recording stations of temporary and/or permanent seismic networks (Italian National Seismic Net- work operated by INGV and Italian Strong Motion Network operated by the Italian Department of Civil Protection), rescue activities in the epicentral area. The available information was centralized in a web Geographic Information System (Arcgis on-line) to facilitate the data sharing to all Emersito members (Figure 1). During August 26 $6^{\text {th }}-31^{\text {st }}, 22$ temporary seismic stations were installed in four municipalities: Amandola (FM), Civitella del Tronto (TE), Montereale (AQ), and Capitignano (AQ). Additional 5 recording stations were set in Acquasanta Terme (AP) by the INGV National Earthquake Centre in cooperation with the Emersito task force.

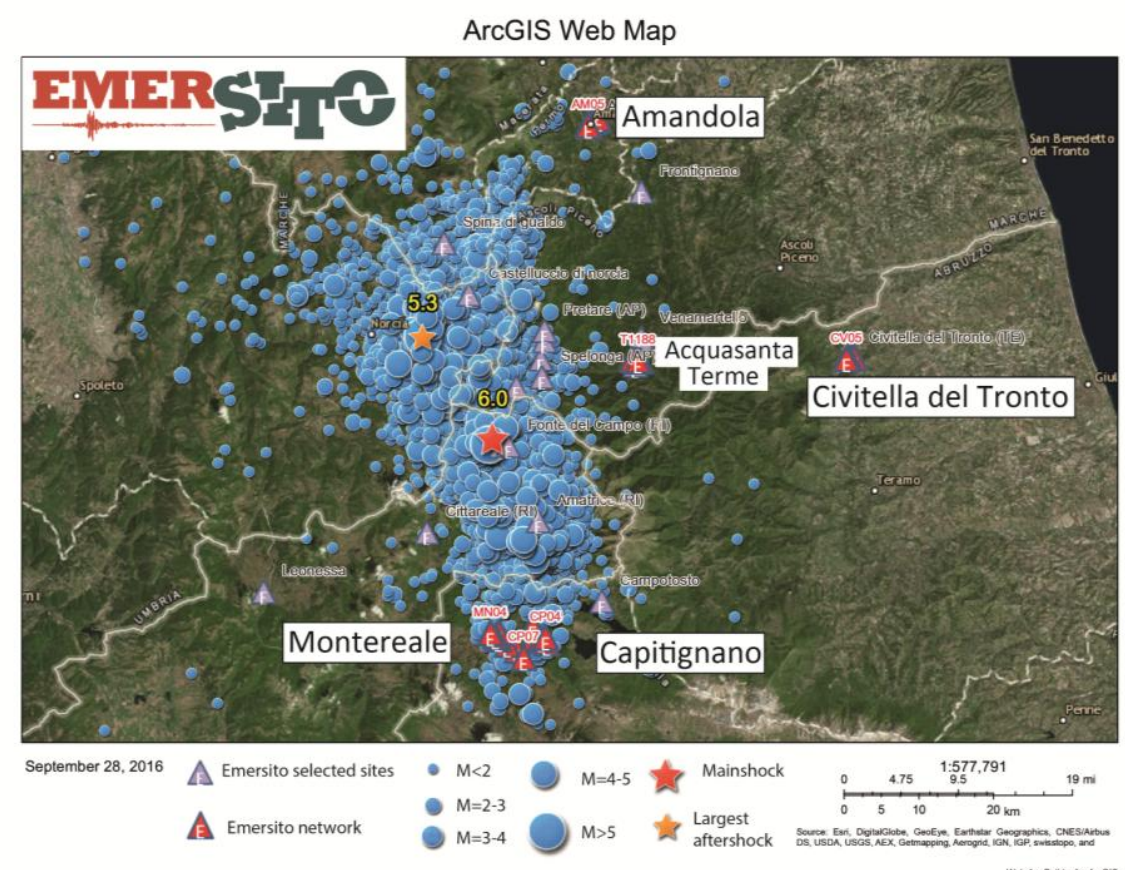

Figure 1. Thematic levels of Emersito ArcGis on-line with the 2016 Amatrice seismic sequence (from August 24th to September 28th) together with the selected sites and the temporary network. 


\section{INSTRUMENTAL SETTING}

The instrumental setting was composed of 22 digitizers (Reftek 130 and Quanterra), equipped with both Lennartz-5s velocimeter and Episensor accelerometer (Emersito report, 2016). All the stations recorded in continuous mode: five of them transferred data to a remote server in real-time, while the remaining stations were in a stand-alone configuration. Data will be distributed through the European Integrated Data Archive (EIDA, http://eida.rm.ingv.it/), by using the international XO code assigned on August, 29th to the temporary Emersito network by the Federation of Digital Seismograph Networks (www.fdsn.org/networks/detail/XO_2016).

The XO network was named "Seismic Network for Site Effect Studies in Amatrice Area (Central Italy)" and the station codes were registered at the International Seismological Centre (ISC) on September $6^{\text {th }}$. Table 1 reports network and station code, municipality, site coordinate, digitizer, sensor, type of seismic data acquisition (real-time vs local), and installation period.

\section{DESCRIPTION OF THE SELECTED SITES AND PRELIMINARY RESULTS}

\section{Amandola}

The village of Amandola is located $30 \mathrm{~km}$ Northeast from the epicentral area (Figure 1). It extends along a relief, with SW-NE trend, constituted by clayey sandstones. Several buildings of the historical center, and also the hospital, suffered some damage after the mainshock. Figure 2 shows the location of the
5 stations (Table 1), which were installed along the ridge and at the base of the relief, with the aim of investigating possible topographic effects. In particular, the hospital area was monitored by AM03 station.

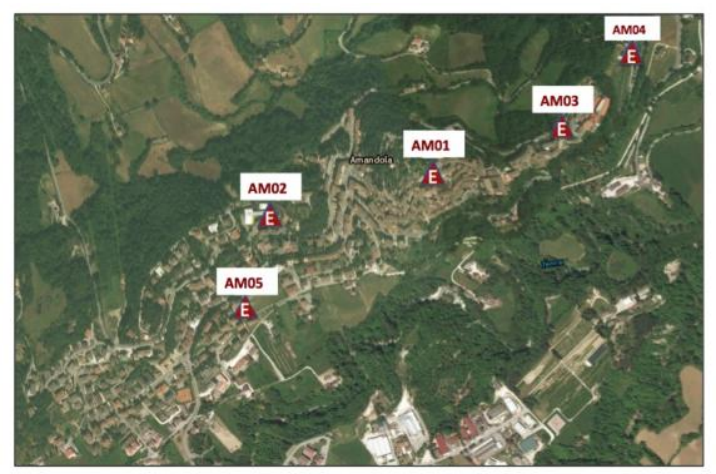

Figure 2. Stations installed at Amandola.

All stations installed at Amandola sent data in real time to the remote INGV acquisition center and were soon available (i.e. in average 2 hours later each event origin time) and downloadable from the real time INGV Strong Motion Database (ISMD; http:/ /ismd.mi.ingv.it). Due to the broadening of the sequence towards North (Gruppo di Lavoro INGV, 2016), AM05 was integrated to the Italian Seismic Network with the aim to improve the location operated by the INGV National Earthquake Centre.

A preliminary analysis of the Horizontal to Vertical Spectral Ratio (HVSR) was performed considering at all stations 1 hour of ambient noise (running window length of 120 seconds, $4^{\text {th }}$ order Butterworth filter in the frequency band $0.1-15 \mathrm{~Hz}$, tapering 5\%, Konno-Ohmachi logarithmic smoothing with $b=20$ ). Possible transient signals were deleted by visual inspection. In general, all stations installed at the top of the ridge show HVSR with amplification ranging from 3 to 4 in the frequency range 3-4 
Hz. The maximum amplification was observed in the N-NW direction (Figure 2); AM05, installed at the base of the ridge, can be considered the reference site in the range of interest for topographic effect, showing amplification at frequency $>8 \mathrm{~Hz}$ due to a very thin layer of landfill. Further investigations are needed to ascribe the recordings behavior to a topographical effect.

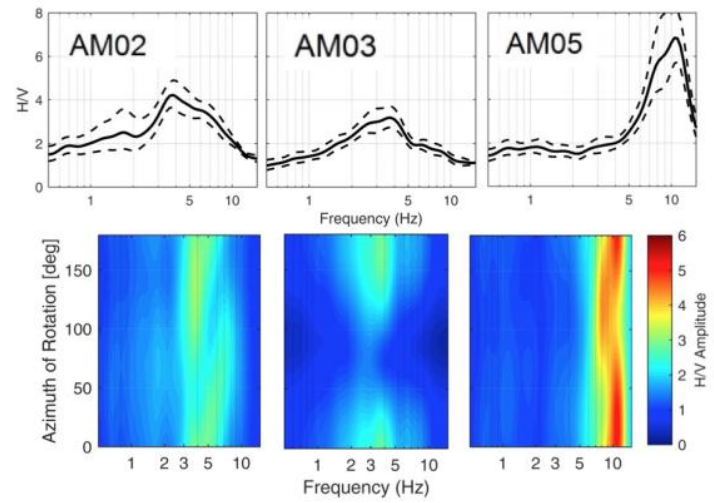

Figure 3. HVSR on noise recorded at AM02, AM03 and AM05: (top) quadratic mean of the two horizontal components \pm 1 standard deviation; (bottom) rotated spectral ratio at different azimuths.

\section{Montereale and Capitignano}

The villages of Montereale and Capitignano are located $20 \mathrm{~km}$ South of the mainshock and in correspondence with the southernmost epicentres of the sequence (Figure 1). Both municipalities suffered slight damage after the mainshock and the larger events. Figure 4 shows the 12 stand-alone stations installed to study topographic and basin effects, as well as to investigate possible fault effects close to CP04, CP05 and CP06 (Table 1).

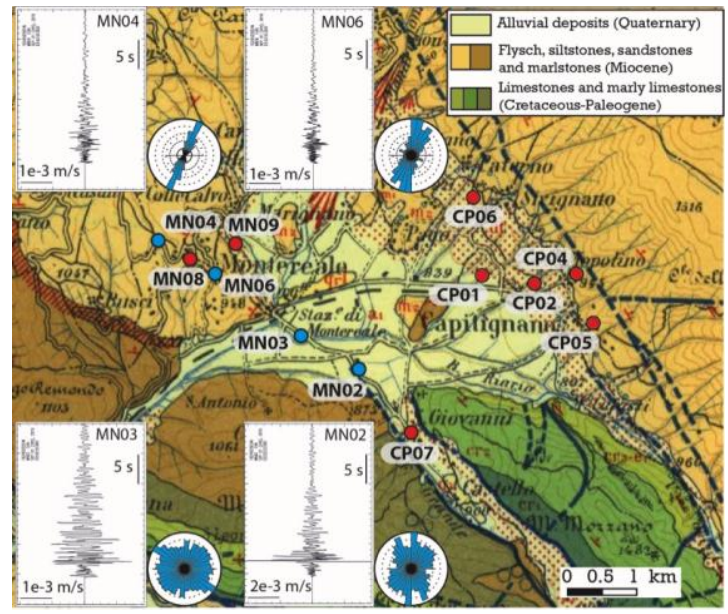

Figure 4. Stations installed at Montereale and Capitignano, superimposed to the Geological map of Italy at 1:100,000 scale. Displayed seismograms refer to the recorded NS component of the $\mathrm{Ml} 3.6$ earthquake (01/09/2016 03:53, hypocentral distance $R=16 \mathrm{~km})$; rose diagrams indicate the horizontal polarization averaged on 19 earthquakes with $M l \geq 3$ recorded in the period 30/081/09/2016.

MN04, MN08 and MN06 are located on the top of a topographic irregularity, characterized by a maximum height of $140 \mathrm{~m}$ from the nearby level ground and maximum slope of $18^{\circ}$. They are on Miocene flysch units (Figure 4 ) and, as a first approximation, they can be considered stiff rock sites. Signal polarization analysis performed in the time domain (Jurkevics, 1988) indicates a predominant N-NE/S-SW direction of the horizontal motion at these sites (Figure 4). The directional amplification effect is confirmed by the HVSR performed on noise and on earthquakes (MN04 in Figure 5).

The stations on Quaternary alluvial deposits are affected by the lengthening and amplification of the seismograms (MN02 and MN03 in Figure 4). At those stations, signal polarization analysis shows an isotropic distribution of po- 
larization azimuths, i.e. the site tends to produce a similar amplitude level on the two horizontal components. Moreover, the HVSR on noise recorded at $\mathrm{MN} 02$ and $\mathrm{CP} 07$ show an amplification peak at $1.5 \mathrm{~Hz}$ and $6 \mathrm{~Hz}$, respectively, that it is probably related to a different thickness of the basin deposits (Figure 5). Further investigations are needed to verify the persistence of the behavior and the correlation with the topography.
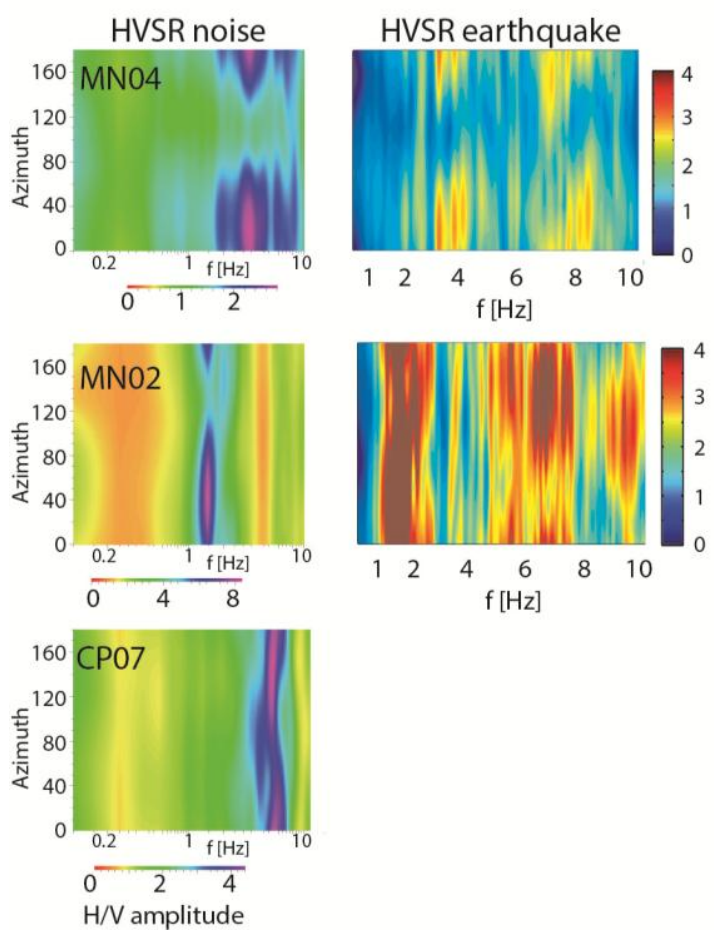

Figure 5. Rotated HVSR on noise (left) and on earthquakes (right) recorded at MN04, MN02 and CPT07 of Figure 4. The HVSR on earthquakes is averaged on 19 events with $M l=3.0 \div 3.9$ recorded in the period 30/081/09/2016; CP07 data were not available in this period.

\section{Civitella del Tronto}

Civitella del Tronto, a village located at about 30-40 km East of the epicentral area (Figure 1), did not suffer significant structural damages for the August $24^{\text {th }}$ mainshock. The municipality is located on a topographic relief, with a SW-NE trend, consisting of travertine overlaying sandstones. Five stand-alone stations were installed along the top and at the base of the relief to detect possible topographic effects (Figure 6). Data were not available at the time of this study because the stations were dismounted at the end of September 2016.

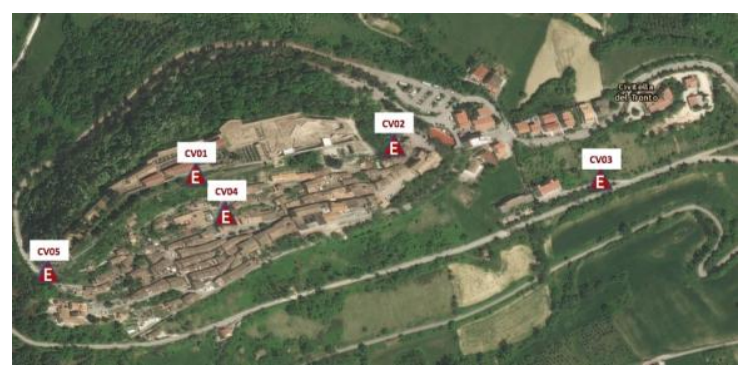

Figure 6. Location of the stations installed at Civitella del Tronto.

\section{CONCLUSIVE REMARKS}

The Emersito efforts during the 2016 Amatrice seismic emergency consisted in the deployment of 22 stations equipped with both velocimeter and accelerometer within few days after the mainshock of August 24 ${ }^{\text {th }}$ 2016, with the aim of studying site effects for selected areas. Usually, these studies use background seismicity while during a seismic sequence stronger events are available and they can be recorded with a rapid installation of a temporary seismic network.

Due to the morphology of the settlements stroke by the earthquake, we focused in the investigation of the site effects of topography, small intra-mountain basin and fault zone to seismic motion. Preliminary results suggest the presence of such effects, requiring further 
analyses to assess the correlation with surface geology. The collected dataset will be available in EIDA node and could support other seismological studies (e.g. source and directivity effects, role of fluids, earthquake location).

The remarks in this paper refer to the first phase of the Central Italy seismic sequence, up to the end of September 2016; at the time of publication, several large magnitude earthquakes that contributed to modify the damaging level of the studied villages have hit the area.

\section{ACKNOWLEDGEMENTS}

We are grateful to the local authorities and the inhabitants of the investigated municipalities that supported us during the network management. The study benefited from funding provided by the Italian Presidenza del Consiglio dei Ministri, Dipartimento della Protezione Civile (DPC); scientific papers funded by DPC do not represent its official opinion and policies.

\section{REFERENCES}

[Bindi et al., 2009] Bindi, D and Parolai, $S$ and Cara, F and Di Giulio, G and Ferretti, G and Luzi, L and Monachesi, G and Pacor, F and Rovelli, A (2009). Site amplifications observed in the Gubbio Basin, Central Italy: hints for lateral propagation effects. Bulletin of the Seismological Society of America, 99(2A), 741-760.

[Bordoni et al, 2012] Bordoni, P., Azzara, R.M., Cara, F., Cogliano, R., Cultrera, G., Di Giulio, G., Fodarella, A., Milana, G., Pucillo, G.,Riccio G., Rovelli, A., Augliera, P.,Luzi, L., Lovati, S.,Massa, M., Pacor, F., Puglia, R., Ameri, G. (2012). Preliminary results from EMERSITO, a rapid response network for site-effect studies. Annals of Geophysics, 55, 4, 2012; doi: 10.4401/ag-6153.
[Chaljub et al, 2010] Chaljub, E., Moczo, P., Tsuno, S., Bard, P. Y., Kristek, J., Käser, M., Stupazzini, M., Kristekova, M. (2010). Quantitative comparison of four numerical predictions of 3D ground motion in the Grenoble valley, France. Bulletin of the Seismological Society of America, 100(4), 1427-1455.

[DDG, 2015] Decreto Direttore Generale INGV n. 337 e Allegati, 2015; http:/ / istituto.ingv.it/1ingv/amministrazione-trasparente-

1/contenuti-at-vari/decreti/anno-2015decreti-presidente-e-direttore-generale).

[Di Giulio et al, 2016] Di Giulio, G., de Nardis, R., Boncio, P., Milana, G., Rosatelli, G., Stoppa, F., Lavecchia, G. (2016). Seismic response of a deep continental basin including velocity inversion: the Sulmona intramontane basin (Central Apennines, Italy). Geophysical Journal International, 204(1), 418-439.

[Emersito report, 2016] EMERSITO working group (2016). Rapporto preliminare sulle attività svolte dal gruppo operativo EMERSITO a seguito del terremoto di Amatrice Mw 6.0 (24 agosto 2016, Italia centrale). doi: 10.5281/zenodo.151655

[INGV working group, 2016] INGV working group on the Amatrice earthquake (2016). Second summary report on the M6.0 Amatrice earthquake of August 24, 2016 (Central Italy), doi: $10.5281 /$ zenodo. 16624

Jurkevics, A. (1988), Polarization analysis of three component array data, Bull. Seismol. Soc. Am., 78, 1725-1743.

[Kawase, 1996] Kawase, H. (1996). The cause of the damage belt in Kobe: the basin-edge effect, constructive interference of the direct S-wave with the basin-induced diffracted/Rayleigh waves. Seismol Res Lett, 67:25-34. 
[Massa, 2014] Marco Massa, Simone Barani and Sara Lovati, Overview of topographic effects based on experimental observations: meaning, causes and possible interpretations, Geophysical Journal International, doi: $10.1093 /$ gji/ggt341.

[Paolucci, 2002] Paolucci, R. (2002). Amplification of earthquake ground motion by steep topographic irregularities. Earthq. Eng. Struct. Dyn., 31:1831-1853.

[Pischiutta et al., 2012] Pischiutta, M., Salvini, F., Fletcher, J., Rovelli, A., \& Ben-Zion, Y. (2012). Horizontal polarization of ground motion in the Hayward fault zone at Fremont,
California: dominant fault-high-angle polarization and fault-induced cracks. Geophysical Journal International, 188(3), 1255-1272.

[Pondrelli et al., (2016)] Pondrelli, S., Amato, A., Massa, M., Montone, P., Crescimbene, M., La Longa, F., Emergenza sismica working group (2016). "Pianificazione e gestione di un'emergenza sismica: esercitazione INGV del 26 novembre 2015 effettuata nell'ambito della Linea di Attività T5 "Sorveglianza sismica e operatività post terremoto". Quaderni di Geofisica, 317, novembre 2016. ISSN 1590-2595 [in Italian]. 
ANNALS OF GEOPHYSICS, 59, Fast Track 5, 2016; DOI: 10.4401/ag-7189

Table 1. Emersito seismic stations installed at the beginning of the 2016 Amatrice seismic emergency (network code XO)

\begin{tabular}{|c|c|c|c|c|c|c|c|c|c|}
\hline Station code & Municipality & Lat. $\left[{ }^{\circ}\right]$ & Lon. $\left[{ }^{\circ}\right]$ & Elev. [m] & Digitizer & Vel. Sensor & Acc. Sensor & Acquisition & Installation period \\
\hline AM01 & Amandola & 42.980556 & 13.358708 & 549 & REFTEK130 & LE3D-5S & EPISENSOR & Real-time & $29 / 08-10 / 10 / 2016$ \\
\hline AM02 & Amandola & 42.979597 & 13.353573 & 516 & REFTEK130 & LE3D-5S & EPISENSOR & Real-time & $30 / 08-10 / 10 / 2016$ \\
\hline AM03 & Amandola & 42.981622 & 13.362768 & 511 & REFTEK130 & LE3D-5S & EPISENSOR & Real-time & $29 / 08-10 / 10 / 2016$ \\
\hline AM04 & Amandola & 42.983345 & 13.365007 & 455 & REFTEK130 & LE3D-5S & EPISENSOR & Real-time & $30 / 08-10 / 10 / 2016$ \\
\hline AM05 & Amandola & 42.977404 & 13.352786 & 464 & REFTEK130 & LE3D-5S & EPISENSOR & Real-time & from 30/08/2016 \\
\hline CV01 & Civitella del Tronto & 42.772736 & 13.666229 & 642 & Q330 & LE3D-5S & EPISENSOR & Stand-alone & $31 / 08-26 / 09 / 2016$ \\
\hline CV02 & Civitella del Tronto & 42.773104 & 13.669496 & 600 & Q330 & LE3D-5S & EPISENSOR & Stand-alone & $30 / 08-26 / 09 / 2016$ \\
\hline CV03 & Civitella del Tronto & 42.772644 & 13.672969 & 540 & Q330 & LE3D-5S & EPISENSOR & Stand-alone & $30 / 08-26 / 09 / 2016$ \\
\hline CV04 & Civitella del Tronto & 42.772273 & 13.666690 & 585 & Q330 & LE3D-5S & EPISENSOR & Stand-alone & $31 / 08-26 / 09 / 2016$ \\
\hline CV05 & Civitella del Tronto & 42.771551 & 13.663721 & 605 & Q330 & LE3D-5S & EPISENSOR & Stand-alone & $31 / 08-26 / 09 / 2016$ \\
\hline СР01 & Capitignano & 42.52458 & 13.28758 & 885 & REFTEK130 & LE3D-5S & EPISENSOR & Stand-alone & 29/08-17/09/2016 \\
\hline $\mathrm{CP02}$ & Capitignano & 42.52389 & 13.29596 & 898 & REFTEK130 & LE3D-5S & EPISENSOR & Stand-alone & 29/08-19/09/2016 \\
\hline $\mathrm{CP} 04$ & Capitignano & 42.52529 & 13.30163 & 957 & REFTEK130 & LE3D-5S & --- & Stand-alone & $30 / 08-16 / 09 / 2016$ \\
\hline СР05 & Capitignano & 42.52052 & 13.30267 & 925 & REFTEK130 & LE3D-5S & EPISENSOR & Stand-alone & 29/08-16/09/2016 \\
\hline СP06 & Capitignano & 42.53498 & 13.28591 & 900 & REFTEK130 & LE3D-5S & EPISENSOR & Stand-alone & 29/08-17/09/2016 \\
\hline СР07 & Capitignano & 42.50748 & 13.27508 & 842 & REFTEK130 & LE3D-5S & EPISENSOR & Stand-alone & $30 / 08-16 / 09 / 2016$ \\
\hline MN02 & Montereale & 42.51393 & 13.26704 & 827 & REFTEK130 & LE3D-5S & EPISENSOR & Stand-alone & $26 / 08-16 / 09 / 2016$ \\
\hline MN03 & Montereale & 42.51916 & 13.25532 & 823 & REFTEK130 & LE3D-5S & EPISENSOR & Stand-alone & $26 / 08-17 / 09 / 2016$ \\
\hline MN04 & Montereale & 42.52906 & 13.23519 & 977 & REFTEK130 & LE3D-5S & EPISENSOR & Stand-alone & $27 / 08-16 / 09 / 2016$ \\
\hline MN06 & Montereale & 42.52400 & 13.24480 & 923 & REFTEK130 & LE3D-5S & EPISENSOR & Stand-alone & $26 / 08-16 / 09 / 2016$ \\
\hline MN08 & Montereale & 42.52624 & 13.24125 & 916 & REFTEK130 & LE3D-5S & EPISENSOR & Stand-alone & $27 / 08-16 / 09 / 2016$ \\
\hline MN09 & Montereale & 42.52987 & 13.24546 & 827 & REFTEK130 & LE3D-5S & EPISENSOR & Stand-alone & $27 / 08-16 / 09 / 2016$ \\
\hline
\end{tabular}

